\title{
Preoperative Lung Ultrasound to Detect Pleural Adhesions: A Systematic Review and Meta- Analysis
}

\author{
Akihiro Shiroshita ${ }^{1}$, Kiyoshi Nakashima ${ }^{1}$, Masafumi Takeshita ${ }^{1}$, Yuki Kataoka ${ }^{2}$ \\ 1. Department of Respiratory Medicine, Ichinomiyanishi Hospital, Ichinomiya, JPN 2. Hospital Care Research Unit, \\ Hyogo Prefectural Amagasaki General Medical Center, Amagasaki, JPN
}

Corresponding author: Akihiro Shiroshita, akihirokun8@gmail.com

\begin{abstract}
The usage of lung ultrasound as a preoperative examination for thoracic surgeries remains controversial. Our systematic review and meta-analysis aimed to evaluate preoperative lung ultrasound diagnostic accuracy for detecting pleural adhesions.
\end{abstract}

We searched articles published in MEDLINE, Embase, CENTRAL, and the International Clinical Trials Registry Platform until October 2020. Inclusion criteria were observational studies, case-control studies, and case series assessing preoperative lung ultrasound diagnostic accuracy. The study quality of included articles was evaluated using the modified quality assessment of diagnostic accuracy studies- 2 tool. The pooled sensitivity and specificity were calculated using the bivariate random-effects model. The overall quality of evidence was summarized using the grading of recommendations, assessment, development, and evaluation approach.

Eleven articles were included in our systematic review. A high risk of bias was noted regarding undefined pleural adhesions and non-predefined pathological diagnosis. Based on the ten articles included for metaanalysis, the pooled sensitivity and specificity were $71 \%$ [95\% confidence interval (CI), 56\%-82\%], and 96\% (95\% CI, 89\%-99\%), respectively. The overall quality of evidence was moderate.

Our systematic review revealed that lung ultrasound had high specificity. It may serve as a rule-in test for detecting pleural adhesions before thoracic surgeries, which may assist surgeons in preparation for a prolonged surgery or increased risk of complications that occurred by trocar insertion such as bleeding and persistent air leak.

Review began 04/15/2021 Review ended 04/27/2021 Published 05/06/2021

๑) Copyright 2021 Shiroshita et al. This is an open access article distributed under the terms of the Creative Commons Attribution License CC-BY 4.0., which permits unrestricted use, distribution, and reproduction in any medium, provided the original author and source are credited.
Categories: Medical Simulation, Pulmonology

Keywords: ultrasonography, systematic review, thoracic surgery, thoracoscopy

\section{Introduction And Background}

Pleural adhesions between the visceral and pleural walls are a common condition encountered during thoracic surgeries, occurring in approximately $26 \%$ of the patients undergoing these procedures [1]. They are associated with increased mortality and operative time in thoracic surgery, especially during thoracoscopy [2]. Preoperative assessment of pleural adhesions may be important for the evaluation of surgical risk; further, based on the extent of pleural adhesions, surgeons may choose to modify the location of the trocar placement or convert a thoracoscopy procedure to an open thoracotomy [3].

To date, no gold standard technique has been established for identifying pleural adhesions before a thoracic surgery. Computed tomography (CT) is a static imaging modality and has proven to be difficult for the assessment of pleural adhesions (sensitivity, 72\%; specificity, 71\%) [4].

In contrast, ultrasound is a radiation-free, inexpensive, and quick imaging modality that can yield pleural excursion assessments in only five to 10 minutes [5]. An ultrasound can evaluate the pleura dynamically to visualize the absence of a lung sliding or gliding sign on B-mode images or the presence of a seashore or barcode sign on M-mode images. These findings are expected to facilitate the assessment of pleural adhesions [6-16]. However, the practical value of lung ultrasounds remains controversial as previous articles have been based on single-center studies with small sample sizes and unstandardized protocols. In this systematic review, we aimed to evaluate the diagnostic accuracy of the lung sliding sign in a lung ultrasound as a rule-in test for detecting pleural adhesions before thoracic surgery.

\section{Review}

\section{Methods}

This study was designed as a systematic review and pre-registered in the International Prospective Register 


\section{Cureus}

of Systematic Review (registration number: CRD42020212207). The reporting of this study is based on the preferred reporting items for systematic review and meta-analysis (PRISMA) for diagnostic test accuracy [17].

We performed a comprehensive search in MEDLINE, Embase, the Cochrane Library, and the International Clinical Trials Registry Platform until October 3, 2020, using related terms for lung ultrasound and pleural adhesion) (Table 1).

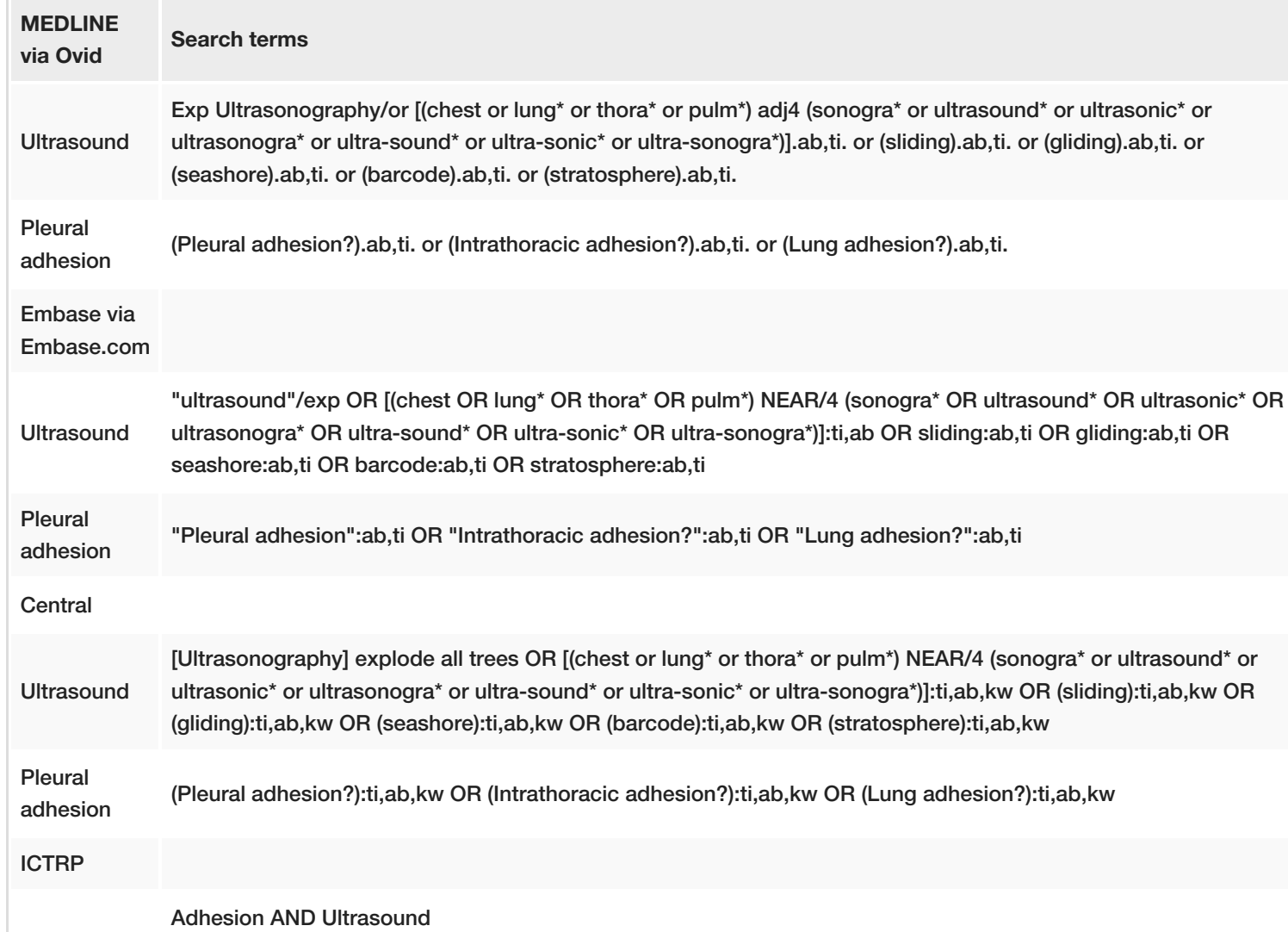

TABLE 1: The search strategy in each database

Additionally, we searched for potentially relevant articles in the reference lists of the included articles and using a citation search in the web of science. Two reviewers (AS and KN) independently screened the eligible studies and then reviewed the full texts. We included prospective and retrospective observational studies, case-control studies, and case series with sufficient data to construct a two-by-two contingency table for the diagnostic yield of preoperative lung ultrasound in detecting pleural adhesions. There were no restrictions on language or publication status. Our target ultrasound findings were the absence of lung sliding or gliding sign on B-mode imaging, and absence of seashore sign, or presence of barcode or stratosphere sign on Mmode imaging (Figure 1 and Figure 2). 


\section{Cureus}

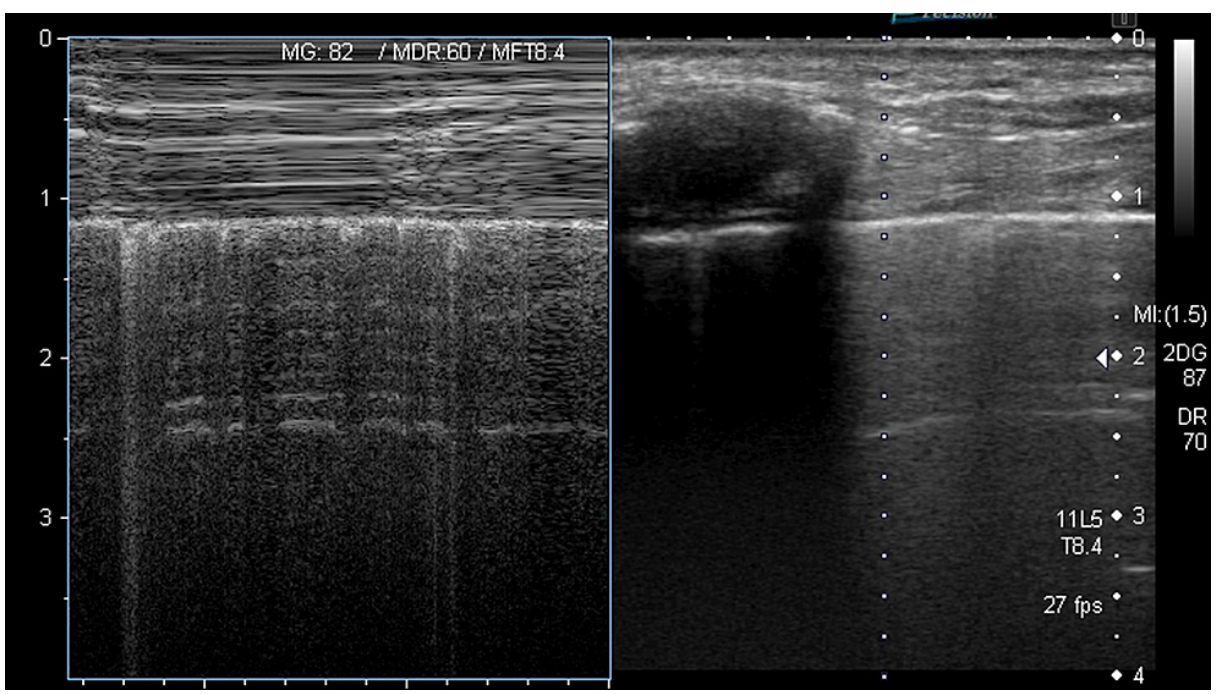

\section{FIGURE 1: Seashore sign}

Seashore sign indicates normal lung sliding. "Sea" is derived from the straight lines created by the subcutaneous tissue and musculature. "Shore" is derived from sand-like appearance created by the continually moving aerated lung below the pleural line.

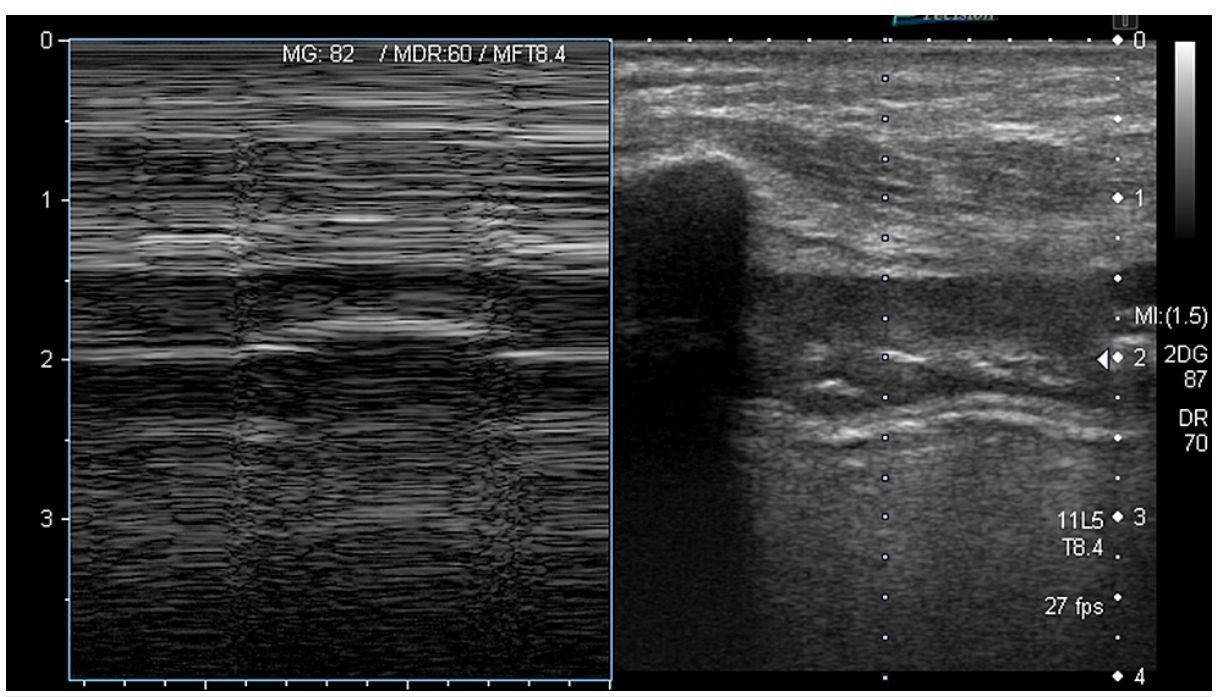

\section{FIGURE 2: Barcode sign}

Barcode sign indicates absence of lung sliding ."Barcode" is derived from parallel horizontal lines below the pleural line.

The sliding or gliding sign refers to the to-and-fro movement of the visceral pleura during breathing [18]; the absence of this finding indicates pleural adhesions. The seashore sign refers to a sand-like appearance beneath the pleural line, whereas the barcode or stratosphere sign refers to linear lines, both superficial and deep to the pleural line [19]. When pleural adhesions are present, the seashore sign is replaced by a barcode/stratosphere sign. As a reference standard, we accepted the confirmation of pleural adhesions by other modalities such as dynamic CT, or through macroscopic findings during thoracoscopy or thoracic surgery. We excluded articles describing emergent or urgent thoracic or cardiac surgery. Review articles, case reports, and animal studies were also excluded.

One of the two reviewers (AS and MT) extracted the data from the included articles, which was then doublechecked. The information extracted from the articles was as follows: country, study design and setting, inclusion criteria, exclusion criteria, number of patients, patient's demographic characteristics, detailed methodology of lung ultrasound, information about the reference standard, and two-by-two contingency tables for diagnostic accuracy (true-positive, false-positive, false-negative, and true-negative). AS and KN evaluated the risk of bias and applicability using the Quality Assessment of Diagnostic Accuracy Studies 


\section{Cureus}

(QUADAS-2) tool (Table 2) [20].

\begin{tabular}{|c|c|c|c|c|}
\hline Domain & Patient selection & Index test & Reference standard & Flow and timing \\
\hline \multicolumn{5}{|l|}{ Risk of bias } \\
\hline $\begin{array}{l}\text { Signaling } \\
\text { questions }\end{array}$ & $\begin{array}{l}\text { Was a consecutive or random } \\
\text { sample of patients enrolled? Was a } \\
\text { case-control design avoided? Did } \\
\text { the study avoid inappropriate } \\
\text { exclusions? }^{\text {a }}\end{array}$ & $\begin{array}{l}\text { Were the } \\
\text { index test } \\
\text { results } \\
\text { interpreted } \\
\text { without } \\
\text { knowledge of } \\
\text { the results of } \\
\text { the reference } \\
\text { standard? If } \\
\text { a threshold } \\
\text { was used, } \\
\text { was it pre- } \\
\text { specified? }\end{array}$ & $\begin{array}{l}\text { Is the reference standard } \\
\text { likely to correctly classify } \\
\text { the target condition? } \\
\text { Were the reference } \\
\text { standard results } \\
\text { interpreted without } \\
\text { knowledge of the results } \\
\text { of the index test? Were } \\
\text { the criteria of reference } \\
\text { standard for target } \\
\text { condition pre-specified? }\end{array}$ & $\begin{array}{l}\text { Was there an appropriate interval } \\
\text { between index test(s) and } \\
\text { reference standard? }{ }^{\mathrm{e}} \text { Did all } \\
\text { patients receive a reference } \\
\text { standard? Did patients receive the } \\
\text { same reference standard? Were all } \\
\text { patients included in the analysis? }^{f}\end{array}$ \\
\hline Explanations & $\begin{array}{l}\text { a: Appropriate exclusions were } \\
\text { defined as excluding patients who } \\
\text { underwent emergency or urgent } \\
\text { thoracic surgery, who had untreated } \\
\text { pneumothorax, massive pleural } \\
\text { effusion, diaphragmatic palsy, and } \\
\text { patients who refused enrollment in } \\
\text { the study. Inappropriate exclusions } \\
\text { were defined as excluding patients } \\
\text { based on antiplatelet use or based } \\
\text { on the information of prior } \\
\text { intrathoracic or breast surgeries, } \\
\text { COPD, obesity, or gynecomastia. }\end{array}$ & $\begin{array}{l}\text { b: The } \\
\text { predefined } \\
\text { definition of } \\
\text { sliding sign } \\
\text { was judged } \\
\text { based on } \\
\text { whether its } \\
\text { cutoff points } \\
\text { were } \\
\text { predefined. }\end{array}$ & $\begin{array}{l}\text { c: We accepted } \\
\text { confirmation of pleural } \\
\text { adhesions by other } \\
\text { modalities than } \\
\text { information during } \\
\text { thoracic operation such } \\
\text { as dynamic CT scan and } \\
\text { macroscopic findings } \\
\text { during medical } \\
\text { thoracoscopy. d: The } \\
\text { predefined pleural } \\
\text { adhesions were judged } \\
\text { whether the degree of } \\
\text { pleural adhesions, such } \\
\text { as dense and light, was } \\
\text { predefined. }\end{array}$ & $\begin{array}{l}\text { e: Appropriate interval between the } \\
\text { ultrasound and operation was } \\
\text { judged to be less than or equal to } \\
60 \text { days before operation. We } \\
\text { decided " } 60 \text { days" based on the } \\
\text { recommendation for re-staging } \\
\text { before surgery by the National } \\
\text { Comprehensive Cancer Network } \\
\text { (NCCN) Clinical Practice Guidelines } \\
\text { in Oncology (NCCN Guidelines). f: } \\
\text { We judged risk of bias based on } \\
\text { whether missing data in the studies } \\
\text { affected the diagnostic accuracy of } \\
\text { ultrasound. }\end{array}$ \\
\hline \multicolumn{5}{|l|}{ Applicability } \\
\hline $\begin{array}{l}\text { Signaling } \\
\text { questions }\end{array}$ & $\begin{array}{l}\text { Is there concern that the included } \\
\text { patients do not match the review } \\
\text { question? }\end{array}$ & $\begin{array}{l}\text { Is there } \\
\text { concern that } \\
\text { the index } \\
\text { test, its } \\
\text { conduct, or } \\
\text { interpretation } \\
\text { differ from } \\
\text { the review } \\
\text { question? }\end{array}$ & $\begin{array}{l}\text { Is there concern that the } \\
\text { target condition as } \\
\text { defined by the reference } \\
\text { standard does not match } \\
\text { the review question? }\end{array}$ & Not applicable \\
\hline
\end{tabular}

TABLE 2: Risk of bias and applicability assessment using the modified Quality Assessment of Diagnostic Accuracy Studies tool.

If disagreements arose between two reviewers during the review process, these were resolved by either a consensus or a consultation with a third reviewer (YK).

AS performed the statistical analyses using StataCorp. 2017. Stata Statistical Software: Release 15. College Station, TX: StataCorp LLC. and Review Manager (RevMan) [Computer program]. Version 5.4, The Cochrane Collaboration, 2020, and KY confirmed the process of the statistical analyses. First, we constructed a forest plot to illustrate the sensitivity and specificity in each study and evaluated the heterogeneity of diagnostic accuracy by calculating the I2 values. Then, regardless of the heterogeneity, we calculated the pooled sensitivity and specificity using the bivariate random-effects model. Additionally, the hierarchical summary receiver operating characteristic (HSROC) curve was generated. As an ad-hoc subgroup analysis, we calculated the sensitivity and specificity among patients with chronic obstructive pulmonary disease (COPD) and those with a body mass index $(\mathrm{BMI}) \geqslant 30$. As a sensitivity analysis, we calculated the sensitivity and 


\section{Cureus}

specificity among studies that used only the B-mode images and in those with a high risk of bias. The overall quality of evidence for lung ultrasound was evaluated using the grading of recommendations, assessment, development, and evaluation (GRADE) approach [21].

\section{Results}

Figure 3 shows the study selection process.

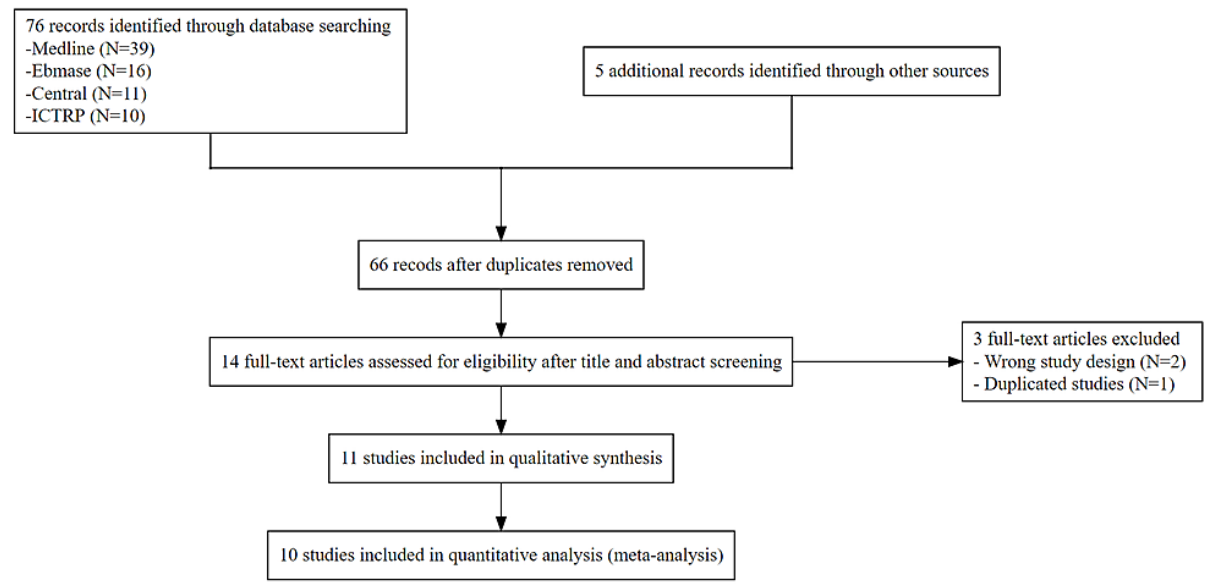

\section{FIGURE 3: PRISMA flow chart}

The excluded articles after full-text screening were as follows:

Wrong study design:

Thiam K, Guinde J, Laroumagne S, Bourinet V, Berbis J, et al. Lateral decubitus chest radiography or chest ultrasound to predict pleural adhesions before medical thoracoscopy: a prospective study. J Thorac Dis. 2019 Oct;11(10):4292-4297.

Nakano N, Oyama S, Kotake Y, Yasumitsu T. Ultrasonographic diagnosis of pleural adhesion in patients with lung cancer. JPN J Med Ultrason 1995;22:27-30.

Duplicated studies:

Jeong H, Ahn HJ, Lee El, Gook JH. Usefulness of chest ultrasonography for prediction of pleural adhesion and postoperative severe pain in thoracoscopic surgery. J Cardiothorac Vasc Anesth. 2019 Sep;33:S114.

(This is the conference abstract of Jeong 2020.)

After screening 66 articles, we included 11 studies in the systematic review [6-16]. Information for the study by Shibasaki was obtained from the principal investigator via email [11]. We extracted the data from a total of 2366 sites in 840 patients who underwent elective thoracic surgery. Among these, 280 patients (33\%) were women. All included studies had been performed at single centers. We have summarized the study characteristics in Table 3 and the lung ultrasound methodologies in Table 4.

\begin{tabular}{|c|c|c|c|c|c|c|}
\hline Study & Country & Study design & Procedures & Exclusions & $\begin{array}{l}\text { Number of } \\
\text { participants }\end{array}$ & $\begin{array}{l}\text { Mean } \\
\text { age } \\
\text { (SD) or } \\
\text { median } \\
\text { [95\% } \\
\text { IQR] }\end{array}$ \\
\hline $\begin{array}{l}\text { Nakano, } \\
1995[6]\end{array}$ & Japan & $\begin{array}{l}\text { Prospective } \\
\text { cohort study }\end{array}$ & Elective thoracotomy for lung tumor & None & 125 & $\begin{array}{l}64.1 \\
\text { (NA) }\end{array}$ \\
\hline $\begin{array}{l}\text { Tateishi, } \\
2001 \text { [7] }\end{array}$ & Japan & $\begin{array}{l}\text { Retrospective } \\
\text { cohort study }\end{array}$ & $\begin{array}{l}\text { Elective thoracoscopy (volume } \\
\text { reduction surgery for severe } \\
\text { pulmonary emphysema, } 11 \text { patients; } \\
\text { thoracoscopic esophagectomy for } \\
\text { esophageal cancer, } 6 \text { patients; } \\
\text { lobectomies for bronchogenic }\end{array}$ & None & 23 & 63 (NA) \\
\hline
\end{tabular}




\section{Cureus}

\begin{tabular}{|c|c|c|c|c|c|c|}
\hline & & & $\begin{array}{l}\text { carcinoma, } 4 \text { patients; and extirpation } \\
\text { of benign mediastinal neoplasms, } 2 \\
\text { patients) }\end{array}$ & & & \\
\hline $\begin{array}{l}\text { Sasaki, } \\
2005[8]\end{array}$ & Japan & $\begin{array}{l}\text { Prospective } \\
\text { cohort study }\end{array}$ & $\begin{array}{l}\text { Scheduled thoracotomy or } \\
\text { thoracoscopy }\end{array}$ & $\begin{array}{l}\text { History of prior chest } \\
\text { surgery }\end{array}$ & 42 & NA \\
\hline $\begin{array}{l}\text { Cassanelli, } \\
2012[9]\end{array}$ & Italy & $\begin{array}{l}\text { Prospective } \\
\text { cohort study }\end{array}$ & Elective thoracotomy or thoracoscopy & $\begin{array}{l}\text { Urgent surgery, untreated } \\
\text { pneumothorax, massive } \\
\text { pleural effusion, } \\
\text { diaphragmatic palsy (78 } \\
\text { cases excluded in total) }\end{array}$ & 64 & $63(13)$ \\
\hline $\begin{array}{l}\text { Wei, } 2012 \\
\text { [10] }\end{array}$ & China & $\begin{array}{l}\text { Prospective } \\
\text { cohort study }\end{array}$ & Elective thoracotomy or thoracoscopy & None & 117 & $59(17)$ \\
\hline $\begin{array}{l}\text { Shibasaki, } \\
2017 \text { [11] }\end{array}$ & Japan & $\begin{array}{l}\text { Prospective } \\
\text { cohort study }\end{array}$ & $\begin{array}{l}\text { Elective thoracoscopy, patient age } \geq \\
20 \text { years }\end{array}$ & Pneumothorax & 81 & 70 (12) \\
\hline $\begin{array}{l}\text { Eshraghi, } \\
2019[12]\end{array}$ & Iran & $\begin{array}{l}\text { Prospective } \\
\text { cohort study }\end{array}$ & $\begin{array}{l}\text { Thoracotomy and thoracoscopy } \\
\text { surgery, patient age between } 20 \text { and } \\
70 \text { years }\end{array}$ & $\begin{array}{l}\text { Heart disease such as } \\
\text { dilated cardiomyopathy } \\
\text { that affects the structure of } \\
\text { the heart, } \mathrm{BMI} \geq 35 \text {, or a } \\
\text { history of gynecomastia or } \\
\text { mastectomy in the past }\end{array}$ & 96 & 45 (14) \\
\hline $\begin{array}{l}\text { Yasukawa } \\
\text { 2019-1, } \\
\text { [13] }\end{array}$ & Japan & $\begin{array}{l}\text { Retrospective } \\
\text { cohort study }\end{array}$ & $\begin{array}{l}\text { Thoracoscopy for reoperations for } \\
\text { ipsilateral pulmonary lesions }\end{array}$ & None & 33 & 67 (14) \\
\hline $\begin{array}{l}\text { Yasukawa } \\
\text { 2019-2, } \\
{[14]}\end{array}$ & Japan & $\begin{array}{l}\text { Retrospective } \\
\text { cohort study }\end{array}$ & Thoracoscopy for aspirin users & $\begin{array}{l}\text { Anticoagulation drugs } \\
\text { and/or antiplatelet drugs } \\
\text { other than aspirin }\end{array}$ & 38 & $73(7)$ \\
\hline $\begin{array}{l}\text { Homma, } \\
2020[15]\end{array}$ & Japan & $\begin{array}{l}\text { Prospective } \\
\text { cohort study }\end{array}$ & Elective thoracic surgery & $\begin{array}{l}\text { Pneumothorax, } \\
\text { hydrothorax, hemothorax, } \\
\text { pyothorax, chylothorax, } \\
\text { age } \leq 19 \text { or } \geq 90 \text { years, } \\
\text { median sternotomy, } \\
\text { psychiatric disorders that } \\
\text { inhibited participation, and } \\
\text { inappropriate participation }\end{array}$ & 168 & $\begin{array}{l}69[60- \\
75]\end{array}$ \\
\hline $\begin{array}{l}\text { Jeong, } \\
2020[16]\end{array}$ & Korea & $\begin{array}{l}\text { Prospective } \\
\text { cohort study }\end{array}$ & $\begin{array}{l}\text { Elective thoracoscopy. Age } \geq 19 \text { years, } \\
\text { and American Society of } \\
\text { Anesthesiologists physical status I to } \\
\text { III. }\end{array}$ & $\begin{array}{l}\text { Pneumothorax, massive } \\
\text { pleural effusion, emergency } \\
\text { surgery }\end{array}$ & 53 & NA \\
\hline
\end{tabular}

TABLE 3: Study characteristics

Abbreviations: SD, standard deviation; IQR, interquartile range; NA, not available

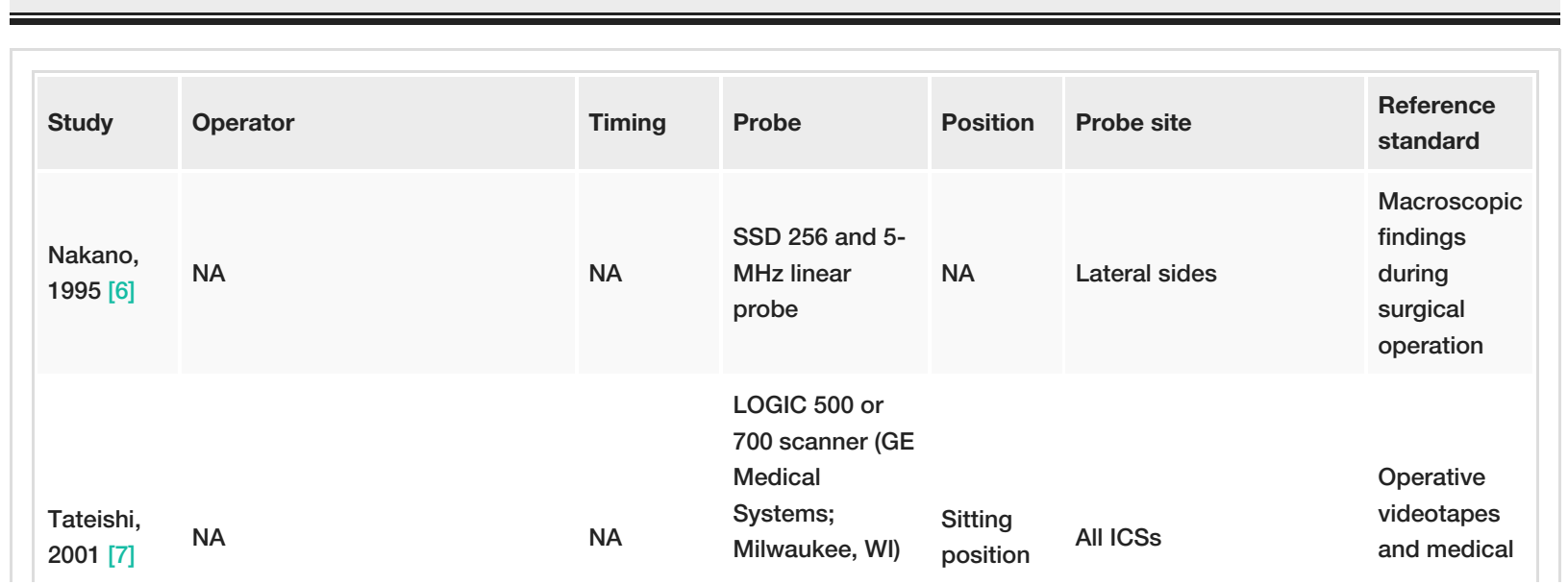




\begin{tabular}{|c|c|c|c|c|c|c|}
\hline & & & $\begin{array}{l}\text { and a } 7-\mathrm{MHz} \\
\text { sector } \\
\text { transducer }\end{array}$ & & & records \\
\hline $\begin{array}{l}\text { Sasaki, } \\
2005[8]\end{array}$ & $\begin{array}{l}\text { After initiation of the study, chest } \\
\text { ultrasonography was interpreted } \\
\text { by the consensus read of } 1 \\
\text { thoracic surgeon and } 1 \\
\text { radiologist for } 3 \text { patients. } \\
\text { Afterwards, chest } \\
\text { ultrasonography is performed by } \\
2 \text { thoracic surgeons for the } \\
\text { remaining 39patients. }\end{array}$ & $\begin{array}{l}\text { Within a } \\
\text { week prior } \\
\text { to the } \\
\text { scheduled } \\
\text { surgery }\end{array}$ & $\begin{array}{l}\text { LOGIQ500 } \\
\text { MR3plus (GE } \\
\text { Yokogawa } \\
\text { Medical } \\
\text { Systems, Tokyo, } \\
\text { Japan) 7-MHz } \\
\text { array B-mode } \\
\text { scanner. }\end{array}$ & $\begin{array}{l}\text { Sitting } \\
\text { position }\end{array}$ & $\begin{array}{l}\text { Seven points in the ICSs. } \\
\text { The midclavicular line in } \\
\text { the 2nd ICS, the } \\
\text { midaxillary and } \\
\text { paravertebral lines in the } \\
\text { 3rd ICS, the midaxillary } \\
\text { and midclavicular lines } \\
\text { in the 7th ICS, and the } \\
\text { scapular lines in the 5th } \\
\text { and 9th ICSs. }\end{array}$ & $\begin{array}{l}\text { Macroscopic } \\
\text { findings } \\
\text { during } \\
\text { surgical } \\
\text { operation }\end{array}$ \\
\hline $\begin{array}{l}\text { Cassanelli, } \\
2012 \text { [9] }\end{array}$ & $\begin{array}{l}\text { Two thoracic surgeons trained in } \\
\text { TUS }\end{array}$ & $\begin{array}{l}\text { On the } \\
\text { day of the } \\
\text { operation }\end{array}$ & $\begin{array}{l}\text { Sonograph GE } \\
\text { (Fairfield, CT, } \\
\text { USA) Logiq® } 7 \text {. } \\
\text { A 3.5-5-MHz } \\
\text { convex } \\
\text { transducer in B- } \\
\text { and M-modes }\end{array}$ & $\begin{array}{l}\text { Sitting } \\
\text { position }\end{array}$ & $\begin{array}{l}\text { Seventeen lung } \\
\text { segments }\end{array}$ & $\begin{array}{l}\text { Macroscopic } \\
\text { findings } \\
\text { during } \\
\text { surgical } \\
\text { operation } \\
\text { interpreted } \\
\text { by a surgeon }\end{array}$ \\
\hline $\begin{array}{l}\text { Wei, } 2012 \\
\text { [10] }\end{array}$ & One radiologist & $\begin{array}{l}\text { Within } 1 \\
\text { week prior } \\
\text { to the } \\
\text { scheduled } \\
\text { surgery }\end{array}$ & $\begin{array}{l}\text { a } 7 \mathrm{~L} 49 \mathrm{MHz} \\
\text { linear } \\
\text { transducer in B- } \\
\text { mode }\end{array}$ & $\begin{array}{l}\text { Lateral } \\
\text { decubitus } \\
\text { position } \\
\text { lying on } \\
\text { the non- } \\
\text { affected } \\
\text { side }\end{array}$ & $\begin{array}{l}\text { 6th ICS in the midaxillary } \\
\text { line }\end{array}$ & $\begin{array}{l}\text { Macroscopic } \\
\text { findings } \\
\text { during } \\
\text { surgical } \\
\text { operation } \\
\text { interpreted } \\
\text { by a surgeon }\end{array}$ \\
\hline $\begin{array}{l}\text { Shibasaki, } \\
2017 \text { [11] }\end{array}$ & Anesthesiologists & $\begin{array}{l}\text { After } \\
\text { tracheal } \\
\text { intubation }\end{array}$ & $\begin{array}{l}\text { Sonosite s } \\
\text { nerve (Sonosite, } \\
\text { Inc., Bothell, } \\
\text { WA, USA), linear } \\
\text { 13-6-MHz probe } \\
\text { HFL38 }\end{array}$ & $\begin{array}{l}\text { Lateral } \\
\text { position }\end{array}$ & $\begin{array}{l}3 \text { or } 4 \text { Points marked by } \\
\text { surgeons as port } \\
\text { insertion sites }\end{array}$ & $\begin{array}{l}\text { Macroscopic } \\
\text { findings } \\
\text { during } \\
\text { surgical } \\
\text { operation }\end{array}$ \\
\hline $\begin{array}{l}\text { Eshraghi, } \\
2019 \text { [12] }\end{array}$ & A single radiologist unit & NA & $\begin{array}{l}\text { Ultrasonography } \\
\text { device } \\
\text { manufactured } \\
\text { by Voluson, a } \\
\text { US-based } \\
\text { company, with a } \\
\text { 7-10-5 } \mathrm{MHz} \\
\text { probe }\end{array}$ & NA & $\begin{array}{l}\text { Seven points in the ICSs. } \\
\text { The midclavicular line in } \\
\text { the 2nd ICS, the } \\
\text { midaxillary and } \\
\text { paravertebral lines in the } \\
\text { 3rd ICS, the midaxillary } \\
\text { and midclavicular lines } \\
\text { in the 7th ICS, and the } \\
\text { scapular lines in the 5th } \\
\text { and 9th ICSs. }\end{array}$ & $\begin{array}{l}\text { Macroscopic } \\
\text { findings } \\
\text { during } \\
\text { surgical } \\
\text { operation } \\
\text { interpreted } \\
\text { by surgeons }\end{array}$ \\
\hline $\begin{array}{l}\text { Yasukawa } \\
\text { 2019-1, } \\
\text { [13] }\end{array}$ & NA & $\begin{array}{l}\text { Within } 2 \\
\text { weeks } \\
\text { before the } \\
\text { scheduled } \\
\text { surgery }\end{array}$ & $\begin{array}{l}\text { LOGIQ E9TM } \\
\text { (GE Healthcare, } \\
\text { Chicago, IL, } \\
\text { USA) ultrasound } \\
\text { system }\end{array}$ & $\begin{array}{l}\text { Lateral } \\
\text { position }\end{array}$ & $\begin{array}{l}\text { The mid-axillary lines of } \\
\text { the 7th or 8th ICSs }\end{array}$ & $\begin{array}{l}\text { Macroscopic } \\
\text { findings } \\
\text { during } \\
\text { surgical } \\
\text { operation } \\
\text { interpreted } \\
\text { by surgeons }\end{array}$ \\
\hline $\begin{array}{l}\text { Yasukawa } \\
\text { 2019-2, } \\
\text { [14] }\end{array}$ & NA & $\begin{array}{l}\text { Within } 2 \\
\text { weeks } \\
\text { before the } \\
\text { scheduled } \\
\text { surgery }\end{array}$ & $\begin{array}{l}\text { LOGIQ E10TM } \\
\text { (GE Healthcare, } \\
\text { Chicago, IL, } \\
\text { USA) ultrasound } \\
\text { system }\end{array}$ & $\begin{array}{l}\text { Lateral } \\
\text { position }\end{array}$ & $\begin{array}{l}\text { The mid-axillary lines of } \\
\text { the } 4 \text { th or } 5 \text { th ICSs and } \\
\text { the } 7 \text { th or } 8 \text { th ICSs }\end{array}$ & $\begin{array}{l}\text { Macroscopic } \\
\text { findings } \\
\text { during } \\
\text { surgical } \\
\text { operation } \\
\text { interpreted } \\
\text { by surgeons }\end{array}$ \\
\hline Homma, & & & $\begin{array}{l}\text { A linear-type } \\
\text { ultrasound } \\
\text { probe }(7.5 \mathrm{MHz}) \\
\text { with a Prosound }\end{array}$ & & & $\begin{array}{l}\text { Macroscopic } \\
\text { findings }\end{array}$ \\
\hline
\end{tabular}




\section{Cureus}

\begin{tabular}{|c|c|c|c|c|c|c|}
\hline 2020 [15] & A chief surgeon & NA & $\begin{array}{l}\text { a7 scanner } \\
\text { (Hitachi-Aloka } \\
\text { medical, Ltd. } \\
\text { Tokyo, Japan) }\end{array}$ & NA & Each ICS & $\begin{array}{l}\text { during } \\
\text { surgical } \\
\text { operation }\end{array}$ \\
\hline $\begin{array}{l}\text { Jeong, } \\
2020 \text { [16] }\end{array}$ & $\begin{array}{l}2 \text { anesthesiologists who had } \\
\text { more than } 3 \text { years of experience } \\
\text { in lung ultrasonography. }\end{array}$ & $\begin{array}{l}\text { Before } \\
\text { induction } \\
\text { of } \\
\text { anesthesia }\end{array}$ & $\begin{array}{l}\text { Vivid S70N (GE } \\
\text { Vingmed } \\
\text { Ultrasound AS, } \\
\text { Horten, Norway) } \\
\text { with an } 11 \mathrm{MHz} \\
\text { linear } \\
\text { transducer in B- } \\
\text { mode and M- } \\
\text { mode imaging }\end{array}$ & $\begin{array}{l}\text { Supine } \\
\text { position }\end{array}$ & $\begin{array}{l}\text { The upper and lower } \\
\text { blue points and the } \\
\text { phrenic point, which are } \\
\text { near the } 2 \text { nd ICS in the } \\
\text { midclavicular line, the } \\
\text { 3rd ICS in the anterior } \\
\text { axillary line, and lung- } \\
\text { liver or lung-spleen } \\
\text { junction at the } \\
\text { midaxillary line }\end{array}$ & $\begin{array}{l}\text { Macroscopic } \\
\text { findings } \\
\text { during } \\
\text { surgical } \\
\text { operation }\end{array}$ \\
\hline
\end{tabular}

\section{TABLE 4: Detailed information for the lung ultrasound methodology}

Abbreviations: NA; not available, ICS; intercostal space

Each article contained minimal information about the patients' backgrounds. Data regarding the number of patients with COPD and obesity (BMI $\geqslant 30$ ) could be obtained only from the studies by Cassanelli and Shibasaki $[9,11]$. Lung ultrasound was primarily performed with two-dimensional B-mode imaging; M-mode imaging was only used in two studies as an additional modality when operators had difficulty viewing the pleura with B-mode imaging $[9,16]$. In these two studies, we were unable to find the diagnostic accuracy of each ultrasound sign in either B-mode imaging or M-mode imaging. The macroscopic findings observed during surgery were used as a reference standard.

We evaluated the quality of each study using the QUADAS-2 tool (Figure 4 and Figure 5).

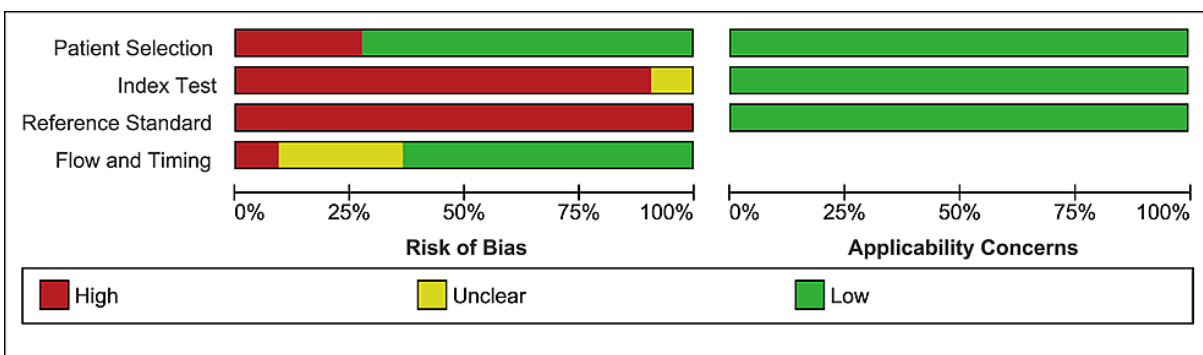

FIGURE 4: Methodological evaluation of thoracic ultrasound using the modified Quality Assessment of Diagnostic Accuracy Studies-2 tool

The high risk-of-bias in the index test and reference standard domain was based on the unspecified methodology of the sliding sign, and not the pre-determined definition of pleural adhesions during thoracic operation. About half of the included articles were identified as having a high risk-of-bias in the patient selection domain due to inappropriate exclusion criteria. 


\section{Cureus}

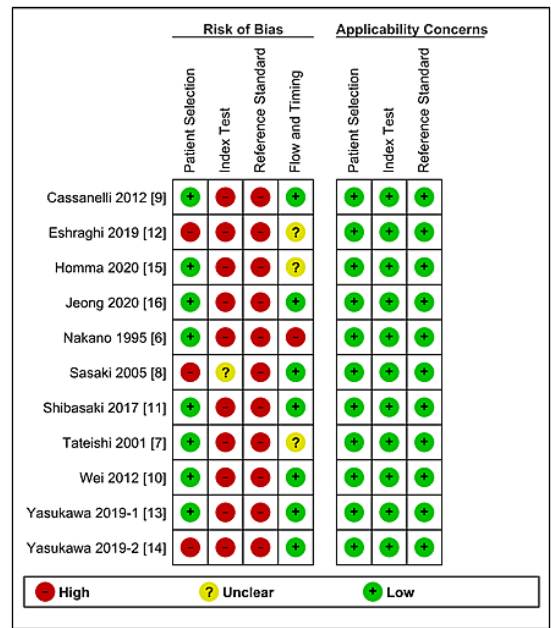

\section{FIGURE 5: Assessment of risk of bias and applicability for each domain in the included studies}

Motoaki Yasukawa wrote 2 articles in 2019, "Yasukawa 2019-1" indicates "Yasukawa M, Taiji R, Marugami N, Kawaguchi T, Kawai N, Sawabata N, et al. Preoperative detection of pleural adhesions using ultrasonography for ipsilateral secondary thoracic surgery patients. Anticancer Res. 2019;39(8):4249-4252." and "Yasukawa 2019-2" indicates "Yasukawa M, Taiji R, Marugami N, Kawaguchi T, Kawai N, Sawabata N, et al.

Ultrasonography for detecting adhesions: Aspirin continuation for lung resection patients. In Vivo. 2019;33(3):973-8.".

A high risk of bias was identified in the domains of the index test and reference standard in all articles. Further, although Sasaki's study defined the cutoff point for a lung sliding sign, the article did not clarify whether the cutoff point was pre-defined [8]. In other articles, the cutoff points were not defined at all. The pleural adhesions were detected during thoracic surgery; however, a definition of pleural adhesion was provided only in the studies reported by Shibasaki and Yasukawa [11,14].

We constructed a forest plot of sensitivity and specificity for each study, and the heterogeneity of the studies was substantial (I2 = 97, 95\% confidence interval [CI], 94-99) (Figure 6).

Study
Cassanelli 2012 [9]
Eshraghi 2019 [12]
Homma 2020[15]
Jeong $2020[16]$
Nakano $1995[6]$
Sasaki $2005[8]$
Shibasaki 2017 [11]
Wei $2012[10]$
Yasukawa 2019-1 [13]
Yasukawa 2019-2 [14]

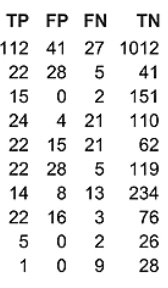

Sensitivity $(95 \% \mathrm{Cl})$
$0.81[0.73,0.87]$
$0.81[0.62,0.94]$
$0.88[0.64,0.99]$
$0.53[0.38,0.68]$
$0.51[0.35,0.67]$
$0.81[0.62,0.94]$
$0.52[0.32,0.71]$
$0.88[0.69,0.97]$
$0.71[0.29,0.96]$
$0.10[0.00,0.45]$

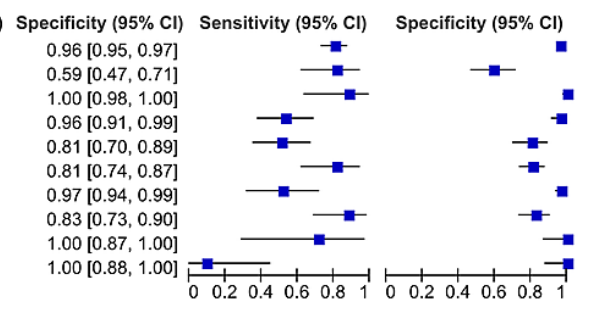

\section{FIGURE 6: The forest plot of sensitivity and specificity in each study}

The forest plot revealed substantial heterogeneity among the included studies. Motoaki Yasukawa wrote 2 articles in 2019, "Yasukawa 2019-1" indicates "Yasukawa M, Taiji R, Marugami N, Kawaguchi T, Kawai N, Sawabata N, et al. Preoperative detection of pleural adhesions using ultrasonography for ipsilateral secondary thoracic surgery patients. Anticancer Res. 2019;39(8):4249-4252." and "Yasukawa 2019-2" indicates "Yasukawa M, Taiji R, Marugami N, Kawaguchi T, Kawai N, Sawabata N, et al. Ultrasonography for detecting adhesions: Aspirin continuation for lung resection patients. In Vivo. 2019;33(3):973-8." 


\section{Cureus}

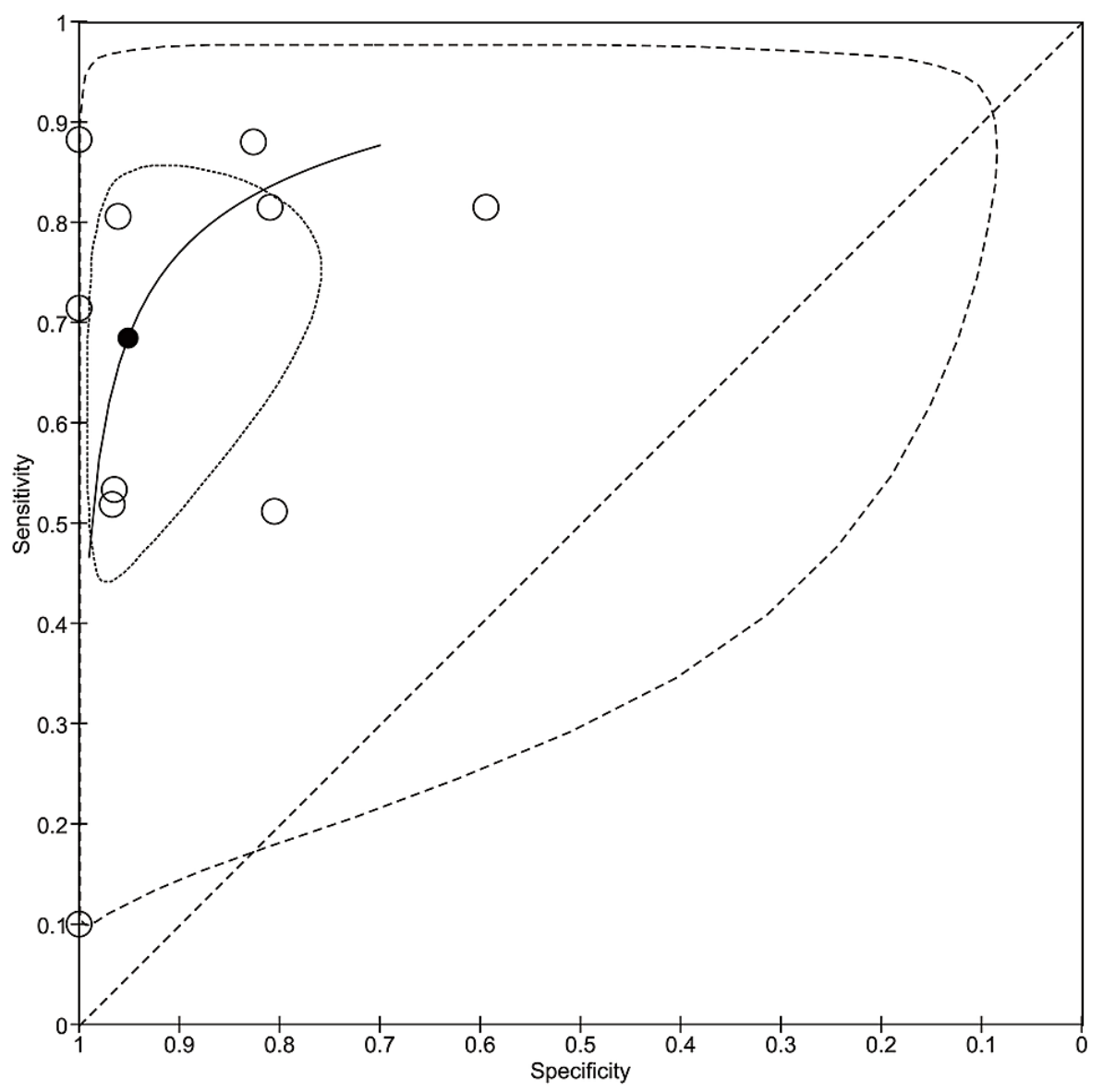

\section{FIGURE 7: The hierarchical summary of the receiver operating characteristics curve of lung ultrasound}

The black circle shows the bivariate summary estimates, the inner dotted line indicates the $95 \%$ confidence region, and the outer dotted line indicates the $95 \%$ prediction region. The hierarchical summary receiver operating characteristic curve is illustrated taking into account of within- and between-study heterogeneity with correlation between sensitivity and specificity. The $95 \%$ confidence region shows an uncertainty of the summary sensitivity and specificity while the $95 \%$ prediction region shows potential values of sensitivity and specificity that could be observed in a future study.

We did not perform an a priori subgroup analysis among patients with COPD or obesity due to a scarcity of information. Our sensitivity analysis targeting studies with a low risk-of-bias in the patient-selection domain and those that underwent only B-mode imaging showed moderate sensitivity and high specificity (pooled sensitivity and specificity, 71\% [95\% CI, 56\%-82\%] and 96\% [95\% CI, 89\%-99\%], respectively, in lowrisk-bias studies; and 68\% [95\% CI, 48\%-83\%] and 95\% [95\% CI, 79\%-99\%], respectively, in B-mode imaging only studies). The overall quality of evidence of lung ultrasound for detecting pleural adhesions, evaluated using the GRADE approach, revealed a moderate certainty of evidence (Table 5). 


\section{Cureus}

\begin{tabular}{|c|c|c|c|c|c|c|c|c|c|c|c|}
\hline \multirow[b]{2}{*}{ Outcome } & \multirow{2}{*}{$\begin{array}{l}\text { Number of studies } \\
\text { (number of patients) }\end{array}$} & \multirow[b]{2}{*}{ Study design } & \multicolumn{5}{|c|}{ Factors that may decrease the certainty of evidence } & \multicolumn{3}{|c|}{ Effect per 1,000 patients tested } & \multirow{2}{*}{$\begin{array}{l}\text { Test } \\
\text { accuracy } \\
\text { certainty of } \\
\text { evidence }\end{array}$} \\
\hline & & & $\begin{array}{l}\text { Risk of } \\
\text { bias }\end{array}$ & Indirectness & Inconsistency & Imprecision & $\begin{array}{l}\text { Publication } \\
\text { bias }\end{array}$ & $\begin{array}{l}\text { Pre-test } \\
\text { probability } \\
\text { of } 50 \%\end{array}$ & $\begin{array}{l}\text { Pre-test } \\
\text { probability } \\
\text { of } 30 \%\end{array}$ & $\begin{array}{l}\text { Pre-test } \\
\text { probability } \\
\text { of } 10 \%\end{array}$ & \\
\hline $\begin{array}{l}\text { True positives (patients with pleural } \\
\text { adhesions) }\end{array}$ & \multirow{2}{*}{$\begin{array}{l}11 \text { studies } 840 \\
\text { patients }\end{array}$} & \multirow{2}{*}{$\begin{array}{l}\text { Cohort \& case- } \\
\text { control type } \\
\text { studies }\end{array}$} & \multirow{2}{*}{$\begin{array}{l}\text { Serious } \\
\text { a }\end{array}$} & \multirow{2}{*}{ Not serious } & \multirow{2}{*}{ Not serious } & \multirow{2}{*}{ Not serious } & \multirow{2}{*}{ None } & $\begin{array}{l}340(265- \\
405)\end{array}$ & $\begin{array}{l}204(159- \\
243)\end{array}$ & $68(53-81)$ & \multirow{2}{*}{$\begin{array}{l}\oplus \oplus \oplus \bigcirc \\
\text { MODERATE }\end{array}$} \\
\hline $\begin{array}{l}\text { False negatives (patients incorrectly } \\
\text { classified as not having pleural adhesions) }\end{array}$ & & & & & & & & $\begin{array}{l}160(95- \\
235)\end{array}$ & $\begin{array}{l}96(57- \\
141)\end{array}$ & $32(19-47)$ & \\
\hline $\begin{array}{l}\text { True negatives (patients without pleural } \\
\text { adhesions) }\end{array}$ & \multirow{2}{*}{$\begin{array}{l}11 \text { studies } 840 \\
\text { patients }\end{array}$} & \multirow{2}{*}{$\begin{array}{l}\text { Cohort \& case- } \\
\text { control type } \\
\text { studies }\end{array}$} & \multirow{2}{*}{$\begin{array}{l}\text { Serious } \\
\text { a }\end{array}$} & \multirow{2}{*}{ Not serious } & \multirow{2}{*}{ Not serious } & \multirow{2}{*}{ Not serious } & \multirow{2}{*}{ None } & $\begin{array}{l}475(425- \\
490)\end{array}$ & $\begin{array}{l}665(595- \\
686)\end{array}$ & $\begin{array}{l}855(765- \\
882)\end{array}$ & \multirow{2}{*}{$\begin{array}{l}\oplus \oplus \oplus \bigcirc \\
\text { MODERATE }\end{array}$} \\
\hline $\begin{array}{l}\text { False positives (patients incorrectly classified } \\
\text { as having pleural adhesions) }\end{array}$ & & & & & & & & $25(10-75)$ & $\begin{array}{l}35(14- \\
105)\end{array}$ & $\begin{array}{l}45(18- \\
135)\end{array}$ & \\
\hline
\end{tabular}

\section{TABLE 5: Findings with pleural adhesions via lung ultrasound using the Grading of}

Recommendation, Assessment, Development and Evaluation approach

a. In most of the included studies, the definitions of the lung sliding sign and pleural adhesions as reference standards were not provided. Approximately half of the included studies excluded patients with prior thoracic surgeries, those taking anticoagulation or antiplatelet drugs, and patients with obesity, gynecomastia, or a prior mastectomy.

\section{Discussion}

We aimed to evaluate whether lung ultrasound may be performed as a rule-in test for detecting pleural adhesions before thoracic surgeries. Our systematic review and meta-analysis showed that lung ultrasound had a high specificity for detecting pleural adhesions before thoracic surgery. Further, the sensitivity of lung ultrasound was observed to be similar to that of CT [4]. Based on the moderate overall quality of evidence, further prospective studies with a definition for pleural adhesions and pre-defined lung sliding signs are needed. Our systematic review and meta-analysis showed that lung ultrasound had a high specificity for detecting pleural adhesions before thoracic surgery [Video 1 and Figure 8]

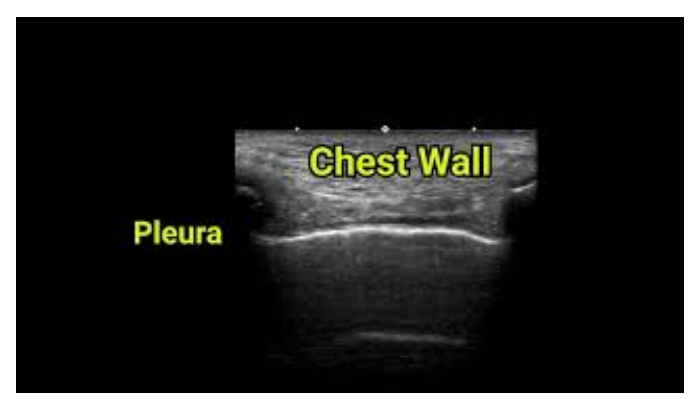

\section{VIDEO 1: Video Abstract}

This video abstract was produced by Akihiro Shiroshtia. Our systematic review revealed that lung ultrasound may serve as a rule-in test for pleural adhesions before thoracic surgeries. Based on the results of the ultrasound, surgeons may be able to prepare for a prolonged duration of surgery and a high risk of associated complications.

View video here: https://www.youtube.com/watch?v=doN5F2zvnRs 


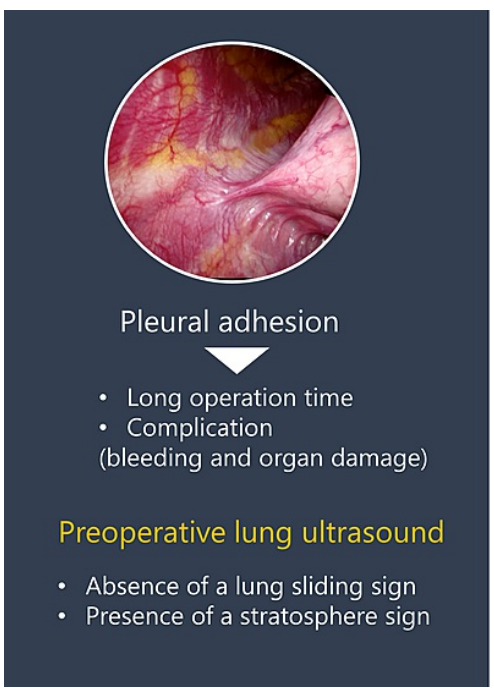

\section{Systematic review \& Meta-analysis}

Preoperative lung ultrasound

Sensitivity $68 \%$ [95\% $\mathrm{Cl}, 53-81 \%]$

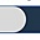

Specificity $95 \%[95 \% \mathrm{Cl}, 85-98 \%]$

Certainty of Evidence

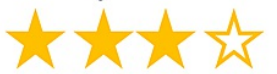

Lung ultrasound would be a rule-in test for detecting pleural adhesions before thoracic surgeries.

FIGURE 8: Graphical Abstract

The high specificity of lung ultrasound supported the diagnosis of pleural adhesions with certainty, and the absence of a sliding sign indicated dense rather than loose pleural adhesions [15]. This information may be used to identify high-risk patients in order to prepare the patient and medical team for prolonged surgeries and the associated complications [2]. In cases where pleural adhesions are identified, changing the trocar insertion site or converting to open thoracotomy may be considered to reduce the risk of bleeding and persistent air leak.

The sensitivity of lung ultrasound was observed to be insufficient to rule out pleural adhesions. However, this may be attributable to the experience level of the operators and the criteria used to identify pleural adhesions. Except for the studies by Cassanelli and Jeong, the remaining studies included in this systematic review did not provide information about the operators' level of experience $[9,16]$. Ultrasound is a relatively new and operator-dependent imaging modality in the field of thoracic surgery [22], and it requires operators with extensive knowledge, experience, and a high level of skill. Since lung sliding signs have been used widely in patients with pneumothorax (sensitivity, $88 \%$; specificity, $99 \%$ ), operators may need to improve their sensitivity in detecting pleural adhesions in such cases [23]. Notably, pleural adhesions were not defined in nearly all of the included articles. Distinguishing between and defining dense vs light ("spider web") adhesions on ultrasound with good sensitivity and specificity is of clinical importance, as $24 \%$ of severe or dense adhesions resulted in postoperative bleeding, compared with only $5 \%$ of light or "spider web" adhesions. Therefore, the focus in future studies should be on dense adhesions.

Among the included articles, the cutoff visceral slide distance was described only in the study by Sasaki [8]. Preoperative assessment of peritoneal adhesions is usually based on whether the distance is less than $2 \mathrm{~cm}$ $[24,25]$. In the upper thoracic cage, pleural movement can be difficult to assess because of the greater distance in the upper thoracic cage between the probe and the pleura than that in the lower thoracic cage $[8,10]$. Thus, a cutoff of $1 \mathrm{~cm}$ in the upper thoracic cage and $2 \mathrm{~cm}$ in the lower thoracic cage may be reasonable, as described by Sasaki [8]. In addition, the probe sites were different between studies and not strictly defined. To date, there are some standardized protocols in other fields. In the field of emergency medicine, a standardized protocol for immediate diagnosis of acute respiratory failure was proposed by Lichtenstein et al [26]. It is a simple protocol composed of three sites (upper, lower, and posterolateral alveolar and/or pleural syndrome point) in each lung based on the size of the patient's two hands [27]. In addition, a computerized program has been evolving for detecting pneumothorax automatically [28]. For a standardized protocol, we may need further studies assessing the diagnostic yield of different cutoff points with standardized probe sites.

This systematic review has several limitations. First, the studies contained minimal background information regarding the patients. Moreover, although lung ultrasound showed high specificity, we were not able to calculate the sensitivity and specificity in specific, more complicated populations, such as those with COPD or obesity. COPD is a major cause of diminishing lung sliding signs due to overinflation of the lungs [26], and the resolution of ultrasound is reduced in obese patients due to excessive fatty tissue [22]. However, among the reviewed studies, 510 out of the 840 patients (61\%) were Japanese individuals with a relatively low BMI [29]. Although we could not estimate why most of the included studies were from Asian countries, a selection from a particular region could limit the generalizability of this review. Second, we were unable to directly assess the patient-reported outcomes. Further studies with larger sample size, especially including patients with COPD and obesity from non-Asian countries, are needed to evaluate patient-reported outcomes and surgical complications, including surgery duration and bleeding. 


\section{Conclusions}

In conclusion, lung ultrasound may serve as a rule-in test for pleural adhesions before thoracic surgery, allowing surgeons to prepare in advance for a prolonged surgery and a high risk of complications, and avoiding certain complications such as bleeding and persistent air leak that can occur as a result of trocar insertion through pleural adhesions.

\section{Additional Information \\ Disclosures}

Conflicts of interest: In compliance with the ICMJE uniform disclosure form, all authors declare the following: Payment/services info: We obtained English editing funding from the Systematic Review Workshop Peer Support Group (SRWS-PSG) (https://community.camp-fire.jp/projects/view/187310). The funder played no role in this study's design and did not have any role in the execution of the study, analysis, or decision to submit results. Financial relationships: All authors have declared that they have no financial relationships at present or within the previous three years with any organizations that might have an interest in the submitted work. Other relationships: All authors have declared that there are no other relationships or activities that could appear to have influenced the submitted work.

\section{Acknowledgements}

The authors would like to thank Seiichi Shibasaki and Saiseikai Yamaguchi General Hospital in the Department of General Internal Medicine for providing us with their research information.

\section{References}

1. Li SJ, Zhou K, Wu YM, et al.: Presence of pleural adhesions can predict conversion to thoracotomy and postoperative surgical complications in patients undergoing video-assisted thoracoscopic lung cancer lobectomy. J Thorac Dis. 2018, 10:416-31. 10.21037/jtd.2017.12.70

2. Zhang Z, Liu D, Guo Y, et al.: The common causes of conversion of vats during operation for 248 non-small cell lung cancers (Article in Chinese). Zhongguo Fei Ai Za Zhi. 2011, 14:523-8. 10.3779/j.issn.10093419.2011.06.08

3. Mason AC, Krasna MJ, White CS: The role of radiologic imaging in diagnosing complications of videoassisted thoracoscopic surgery. Chest. 1998, 113:820-5. 10.1378/chest.113.3.820

4. Mason AC, Miller BH, Krasna MJ, White CS: Accuracy of ct for the detection of pleural adhesions: correlation with video-assisted thoracoscopic surgery. Chest. 1999, 115:423-7. 10.1378/chest.115.2.423

5. Cassanelli N, Caroli G, Dolci G, Dell'Amore A, Luciano G, Bini A, Stella F: Accuracy of transthoracic ultrasound for the detection of pleural adhesions. Eur J Cardiothorac Surg. 2012, 42:813-8;. 10.1093/ejcts/ezs144

6. Eshraghi M, Kachoie A, Sharifimoghadam S: Ultrasonography in the diagnosis of lung adhesion before surgery. Biomol Concepts. 2019, 10:128-32. 10.1515/bmc-2019-0016

7. Tateishi U, Morikawa T, Miyasaka K: Detection of pleural adhesions with sonography. J Clin Ultrasound. 2001, 29:61-2. 10.1002/1097-0096(200101)29:1<61::aid-jcu12>3.0.co;2-k

8. Sasaki M, Kawabe M, Hirai S, Yamada N, Morioka K, Ihaya A, Tanaka K: Preoperative detection of pleural adhesions by chest ultrasonography. Ann Thorac Surg. 2005, 80:439-42. 10.1016/j.athoracsur.2005.03.021

9. Cassanelli N, Caroli G, Dolci G, Dell'Amore A, Luciano G, Bini A, Stella F: Accuracy of transthoracic ultrasound for the detection of pleural adhesions. Eur J Cardiothorac Surg. 2012, 42:813-8; discussion 818. 10.1093/ejcts/ezs144

10. Wei B, Wang T, Jiang F, Wang H: Use of transthoracic ultrasound to predict pleural adhesions: a prospective blinded study. Thorac Cardiovasc Surg. 2012, 60:101-4. 10.1055/s-0030-1270760

11. JPRN-UMIN000030397. Lung Ultrasonography for the Assessment of Pleural Adhesions . (2017). Accessed: April 5, 2021: https://upload.umin.ac.jp/cgi-open-bin/ctr/ctr_view.cgi?recptno=R000034703.

12. Eshraghi M, Kachoie A, Sharifimoghadam S: Ultrasonography in the diagnosis of lung adhesion before surgery. Biomol Concepts. 2019, 10:128-32. 10.1515/bmc-2019-0016

13. Yasukawa M, Taiji R, Marugami N, et al.: Preoperative detection of pleural adhesions using ultrasonography for ipsilateral secondary thoracic surgery patients. Anticancer Res. 2019, 39:4249-52. 10.21873/anticanres. 13587

14. Yasukawa M, Taiji R, Marugami N, et al.: Ultrasonography for detecting adhesions: aspirin continuation for lung resection patients. In Vivo. 2019, 33:973-8. 10.21873/invivo.11566

15. Homma T, Ojima T, Yamamoto Y, Shimada Y, Akemoto Y, Kitamura N, Yoshimura N: Utility of the sliding lung sign for the prediction of preoperative intrathoracic adhesions. J Thorac Dis. 2020, 12:4224-32. $10.21037 /$ jtd-20-886

16. Jeong H, Choi JW, Ahn HJ, Choi J, Park JH: Prediction of pleural adhesions by lung ultrasonography: an observational study. J Cardiothorac Vasc Anesth. 2021, 35:565-70. 10.1053/j.jvca.2020.06.030

17. McInnes MDF, Moher D, Thombs BD, et al.: Preferred reporting items for a systematic review and metaanalysis of diagnostic test accuracy studies: the prisma-dta statement. JAMA. 2018, 319:388-96. 10.1001/jama.2017.19163

18. Frankel HL, Kirkpatrick AW, Elbarbary M, et al.: Guidelines for the appropriate use of bedside general and cardiac ultrasonography in the evaluation of critically ill patients-part I: general ultrasonography. Crit Care Med. 2015, 43:2479-502. 10.1097/CCM.0000000000001216

19. Stone MB: Ultrasound diagnosis of traumatic pneumothorax. J Emerg Trauma Shock. 2008, 1:19-20. 10.4103/0974-2700.41788 


\section{Cureus}

20. Whiting PF, Rutjes AW, Westwood ME, et al.: QUADAS-2: a revised tool for the quality assessment of diagnostic accuracy studies. Ann Intern Med. 2011, 155:529-36. 10.7326/0003-4819-155-8-201110180-00009

21. Schünemann HJ, Mustafa RA, Brozek J, et al.: GRADE guidelines: 21 part 1. Study design, risk of bias, and indirectness in rating the certainty across a body of evidence for test accuracy. J Clin Epidemiol. 2020, 122:129-41. 10.1016/j.jclinepi.2019.12.020

22. Lichtenstein DA, Mezière G, Lascols N, et al.: Ultrasound diagnosis of occult pneumothorax. Crit Care Med. 2005, 33:1231-8. 10.1097/01.ccm.0000164542.86954.b4

23. Ebrahimi A, Yousefifard M, Mohammad Kazemi H, Rasouli HR, Asady H, Moghadas Jafari A, Hosseini M: Diagnostic accuracy of chest ultrasonography versus chest radiography for identification of pneumothorax: a systematic review and meta-analysis. Tanaffos. 2014, 13:29-40.

24. Kolecki RV, Golub RM, Sigel B, et al.: Accuracy of viscera slide detection of abdominal wall adhesions by ultrasound. Surg Endosc. 1994, 8:871-4. 10.1007/BF00843457

25. Borzellino G, De Manzoni G, Ricci F: Detection of abdominal adhesions in laparoscopic surgery. a controlled study of 130 cases. Surg Laparosc Endosc. 1998, 8:273-6.

26. Slater A, Goodwin M, Anderson KE, Gleeson FV: COPD can mimic the appearance of pneumothorax on thoracic ultrasound. Chest. 2006, 129:545-50. 10.1378/chest.129.3.545

27. Lichtenstein DA: BLUE-protocol and FALLS-protocol: two applications of lung ultrasound in the critically ill. Chest. 2015, 147:1659-70. 10.1378/chest.14-1313

28. Summers SM, Chin EJ, Long BJ, et al.: Computerized diagnostic assistant for the automatic detection of pneumothorax on ultrasound: a pilot study. West J Emerg Med. 2016, 17:209-15. 10.5811/westjem.2016.1.28087

29. Sakamoto M: The situation of the epidemiology and management of obesity in Japan . Int J Vitam Nutr Res 2006, 76:253-6. 10.1024/0300-9831.76.4.253 